\title{
Serum Electrolyte Profile of Children Less Than Five Years of Age Admitted with Pneumonia in a Tertiary Care Hospital
}

\author{
Abu Hena Mostafa Kamal, ${ }^{1}$ Sharmin Afrozy, ${ }^{2}$ Marjina Khatun, ${ }^{3}$ \\ Mst Shaheen Nawrozy, ${ }^{4}$ Most. Merina Akhter ${ }^{5}$
}

\begin{abstract}
The study was done to observe whether there is any association of pneumonia with hyponatraemia, as well as to have a view to the patients' hospital-stay in this regard. This study was conducted from July 2009 to September 2011 at the Department of Biochemistry of Shaheed Ziaur Rahman Medical College (SZMC), Bogra. Total 35 cases, 1 month to 5 years of age, who suffered from pneumonia, were included in this study. Their serum $\mathrm{Na}^{+}, \mathrm{K}^{+} \& \mathrm{Cl}$ levels were measured and their hospital stays in days were recorded for the comparison between normonatraemics and hyponatraemics. The distribution patterns were described as percentage of total. In addition, Student's ' $t$ ' test and Pearson's correlation co-efficient test were also used. Among 35 cases, $22(63 \%)$ cases were male and $13(37 \%)$ cases were female; $14(40 \%)$ cases were hyponatraemic and $21(60 \%)$ cases were normonatraemic. Mean ( \pm SD) of age was 19.6 $( \pm 15.2)$ months. For all the cases, there was a positive correlation of serum $\mathrm{Cl}^{-}$with serum $\mathrm{Na}^{+}$ levels $(p<0.001)$; but no correlation was observed between serum $\mathrm{K}^{+} \& \mathrm{Na}^{+}$levels $(P>0.10)$. Hospital stay of hyponatraemic cases was higher than the normonatraemic cases $(P<0.05)$.
\end{abstract}

Children with pneumonia may develop hyponatraemia, which if not managed in due time, may lead to delayed recovery from illness.

Key words: Under five children, Pneumonia, Hyponatraemia.

TAJ 2018; 31: No-2: 59-62

\section{Introduction}

Acute respiratory infection (ARI) is a leading cause of morbidity and mortality of children and is responsible for an estimated 3.9 million deaths worldwide; it is responsible for about $30-50 \%$ visits to health facilities and for about $20-40 \%$ admissions to hospital. ${ }^{1}$

In Bangladesh, about 1250 per lac of $<1$ year old children and about 75 per lac of 1 to $<5$ years old children die of ARI each year. ${ }^{2}$ In India, about 26.3 million cases of ARI were reported in the year
2011, with an incidence rate of about 2,173 cases per lac population. ${ }^{3}$ Whereas, most of these deaths due to ARI are preventable. ${ }^{4}$ Multiple social and environmental factors are associated with ARI in childhood. Risk factors associated with ARI are poverty, malnutrition, low birth weight, inadequate breast feeding, complementary foods initiation, overcrowding, poor housing conditions, air pollution and lack of access to preventive medicine (including immunization) and curative services. ${ }^{5,6}$

\footnotetext{
${ }^{1}$ Assistant Professor \& Head, Department of Biochemistry, Kushtia Medical College, Kushtia

${ }^{2}$ Resident Physician (Paediatrics), Shaheed Ziaur Rahman Medical College Hospital, Bogra

${ }^{3}$ Assistant Professor, Department of Community Medicine, Kumudini Women's Medical College, Mirzapur, Tangail

${ }^{4}$ Junior Consultant, (Obstetrics \& Gynaecology), Sadar Hospital, Nilphamari

${ }^{5}$ Assistant Professor, Department of Obstetrics \& Gynaecology, Rajshahi Medical College, Rajshahi
} 
Syndrome of inappropriate antidiuretic hormone secretion (SIADH) occurs in about one-third of hospitalized children with community acquired pneumonia and is characterized by excessive release of antidiuretic hormone from the posterior pituitary leading to dilutional hyponatraemia - the mechanism for which remains unclear and is associated with poorer outcomes. ${ }^{7}$ Although associated with poor prognosis and increased hospital stay, hyponatraemia is often poorly managed and sometimes under-diagnosed and under-treated. ${ }^{8}$ And, this study was conducted to observe any probable association of pneumonia with hyponatraemia as well as to have a view to the hospital-stay in this regard.

\section{Materials and Methods}

This cross sectional case study was conducted from July 2009 to September 2011 at the Department of Biochemistry of SZMC, Bogra. Sample of this study was collected by purposive sampling technique from the Paediatrics patients of SZMCH, Bogra who attended the Clinical Laboratory of the Department of Biochemistry of
SZMC, Bogra for investigations. A total of 35 cases, 1 month to 5 years of age, who suffered from pneumonia were included in this study. Their serum $\mathrm{Na}^{+}, \mathrm{K}^{+} \& \mathrm{Cl}^{-}$levels were measured within 72 hours of their admission. Their serum $\mathrm{Na}^{+}$ levels were categorized as follows -

Normal: Serum sodium $\geq 135 \mathrm{mmol} / 1$

Mild hyponatraemia: Serum sodium 120 - <135 $\mathrm{mmol} / \mathrm{l}$

Moderate hyponatraemia: Serum sodium 110 $<120 \mathrm{mmol} / \mathrm{l}$

Severe hyponatraemia: Serum sodium $<110$ $\mathrm{mmol} / \mathrm{l}$

Patients' hospital stay (in days) was recorded for the comparison between normonatraemics and hyponatraemics. The distribution patterns were described as percentage of total. In addition Student's ' $t$ ' test and Pearson's correlation coefficient test were also usedif applicable.

\section{Results:}

Among the 35 cases, 22 (63\%) cases were male and 13 (37\%) cases were female and 14 (40\%) were hyponatraemic and 21 (60\%) cases were normonatraemic. Age range was 1 month to 5 years with a mean $( \pm$ SD) of $19.6( \pm 15.2)$ months.

Table I: Serum sodium levels of all the cases

$\begin{array}{lcccc}\text { Serum Sodium level in mmol/l } & \geq \mathbf{1 3 5} & \mathbf{1 2 0} \text { to }<\mathbf{1 3 5} & \mathbf{1 1 0} \text { to }<\mathbf{1 2 0} & <\mathbf{1 1 0} \\ \text { Number of cases }(\mathrm{n}=35) & 21(60 \%) & 12(34 \%) & -- & 2(6 \%)\end{array}$

Table II: Sex distribution among the hyponatraemic \& normonatraemic cases

\begin{tabular}{|c|c|c|}
\hline Sex & $\begin{array}{c}\text { Hyponatraemics }(\mathrm{n}=14) \\
\left(\text { Serum } \mathrm{Na}^{+}<135 \mathrm{mmol} / \mathrm{l}\right)\end{array}$ & $\begin{array}{l}\text { Normonatraemics }(\mathrm{n}=21) \\
\left(\text { Serum } \mathrm{Na}^{+} \geq 135 \mathrm{mmol} / \mathrm{l}\right)\end{array}$ \\
\hline Male (=22 cases) & $9(41 \%)$ & $13(59 \%)$ \\
\hline Female ( $=13$ cases) & $5(38 \%)$ & $8(62 \%)$ \\
\hline Total (=35 cases) & $14(40 \%)$ & $21(60 \%)$ \\
\hline
\end{tabular}

(Odds ratio of male hyponatraemics to female hyponatraemics is 1.108:1)

Table III: Serum $\mathrm{Na}^{+}, \mathrm{K}^{+} \& \mathrm{Cl}^{-}$levels of all the cases

\section{Parameters}

Serum Sodium (Mean \pm SD)

Serum Potassium (Mean \pm SD)

Serum Chloride (Mean \pm SD)
Serum levels (Mean \pm SD)

$133.7 \pm 9.40 \mathrm{mmol} / \mathrm{l}$

$4.33 \pm 0.40 \mathrm{mmol} / \mathrm{l}$

$96.4 \pm 5.20 \mathrm{mmol} / \mathrm{l}$ 
Pearson's correlation coefficient ' $\mathrm{r}$ ' of sodium level with chloride level was "0.918” $(\mathrm{P}<0.001)$ and of sodium level with potassium level was“0.247” ( $\mathrm{P}>0.10)$.

Figure 1: Correlation of serum sodium level with chloride level

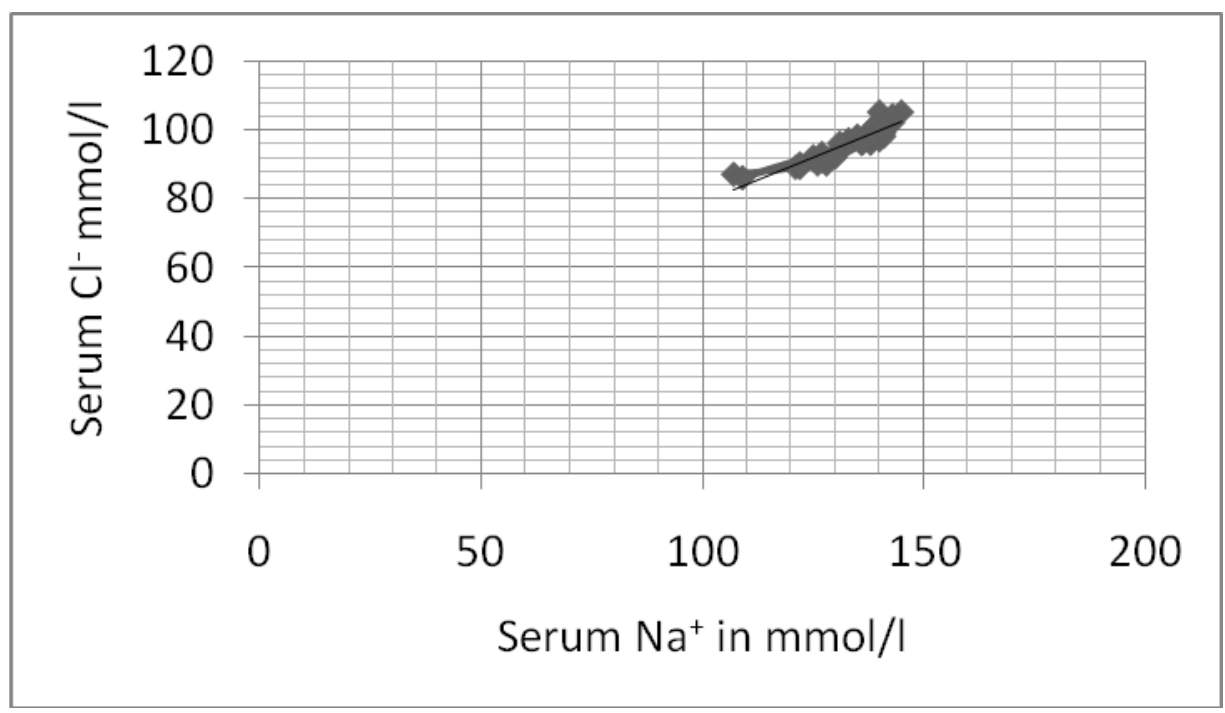

Table IV: Distribution of hypokalaemics among the hyponatraemic \& normonatraemic cases:

\section{Serum Sodium $\mathrm{mmol} / \mathbf{l}$}

Hyponatraemics $(<135)(\mathrm{n}=14)$

Normonatraemics $(\geq 135)(\mathrm{n}=21)$

\section{Serum Potassium \\ $<3.5 \mathrm{mmol} / \mathrm{l}$}

1

0

\section{Serum Potassium}

$\geq 3.5 \mathrm{mmol} / \mathrm{l}$

13

21

Table V: Hospital stay of hyponatraemics and normonatraemics in days

Groups

Hyponatraemics

Normonatraemics

$$
\begin{gathered}
\text { Hospital stay in days } \\
\text { (Mean } \pm \text { SD) } \\
8.1 \pm 3.6(n=13) \\
5.7 \pm 1.5(n=18)
\end{gathered}
$$

't' \&'P' value

$2.26 \&<0.05$

N.B. Hospital stays of 3 normonatraemic cases were excluded because they left hospital on risk bond before complete recovery due to their personal problem. And, also of 1 hyponatraemic case who was hypokalaemic too was excluded; because he expired on $2^{\text {nd }}$ day of admission.

\section{Discussion}

Male children of our study were found to be more affected than the females. Krishnan et al. also found boys to be 2.4 times higher ARI-related hospitalization rate than girls. ${ }^{9}$ BHIS (Jan 2005) also demonstrated male children to be more suffered from pneumonia than female. ${ }^{10}$ Except for sinusitis, otitis externa and probably tonsillitis, another study demonstrated that males develop respiratory tract infections more frequently than females. ${ }^{11}$
Among our cases, 40\% were hyponatraemic. Dhawan et al. mentioned that around one-third (i.e.33\%) of hospitalized children with community acquired pneumonia suffer from hyponatraemia which is, more or less, similar to our study; he also mentioned it to be due to SIADH mediated dilutional hyponatraemia. ${ }^{7} \mathrm{We}$ found a positive correlation of serum $\mathrm{Cl}^{-}$level with serum $\mathrm{Na}^{+}$ level. Generally plasma $\mathrm{Cl}^{-}$level changes in parallel with plasma $\mathrm{Na}^{+}$level. ${ }^{12}$ Dilutional hyponatraemia due to SIADH should also lead to a 
bit low serum $\mathrm{K}^{+}$level; and, pneumonic lung parenchymal damage might have released much $\mathrm{K}^{+}$in ECF that have prevented the fall of serum $\mathrm{K}^{+}$; as well as, high leukocyte count due to pneumonia might also have prevented lowering serum $\mathrm{K}^{+}{ }^{12}$ Among all the cases, 1 hyponatraemic case developed hypokalaemia, who expired 2 days after admission. Probably his hypokalaemia may be due to repeated bronchodilator ( $\beta_{2}$ agonist) therapy to overcome respiratory distress that made potassium intracellular, where under feeding or vomiting might have contributed too. ${ }^{12}$

Hospital stay in days among the hyponatraemics were significantly higher $(p<0.05)$ than the normonatraemics. One study found that, among 7965 patients with pneumonia, hyponatraemia was associated with an increased utilization of ICU support and prolongation of hospital stay $(p<0.001)$ and a trend toward increased hospital mortality $(\mathrm{p}=0.10)^{13}$

\section{Conclusion}

Our sample size is too small to come to a definite conclusion. Still, it appears that some of the pneumonia cases may develop hyponatraemia which if not managed in due time, may lead to delayed recovery from illness with prolongation of hospital stay. So, if any suspicion arises, we should evaluate serum $\mathrm{Na}^{+}$level in patients with pneumonia.

\section{References}

1. Park K. Epidemiology of Communicable Diseases. Park's Textbook of Preventive and Social Medicine, $21^{\text {st }}$ edition, 2011; page 156.

2. Bangladesh Health and Injury Survey, Report on children, January 2005; page 26.
3. National Health Profile (NHP) of India - 2011.

4. Lal S. Epidemiology of Communicable Diseases and Related National Health Programmes. Textbook of Community Medicine. $2^{\text {nd }}$ edition, 2011; page 543.

5. Nair V, Niederman MS, Masani N et al. Hyponatremia in community acquired spneu monia. Am J Nephrol 2007; 27: 184-190.

6. Ellison DH, Berl T. Clinical practice. The syndrome of inappropriate antidiuresis. N Engl J Med 2007; 356: 2064-2072.

7. Dhawan A, Narang A, Singhi S. Hyponatraemia and the inappropriate $\mathrm{ADH}$ syndrome in pneumonia. Ann Trop Pediatr 1992; 12: 455-462.

8. Thompson C \& Hoorn EJ. Hyponatraemia: an overview of frequency, clinical presentation and complications. Best Pract Res Clin Endocrinol Metab. 2012 Mar; 26 (Suppl 1):1-6.

9. Krishnan A, Amarchand R, Gupta $V$, Lafond KE, Suliankatchi RA, Saha S, Rai A, Misra P et al. Epidemiology of acute respiratory infections in children- preliminary results of a cohort in a rural north Indian community. BMC Infectious Diseases 2015; 15: 462.

10. Bangladesh Health and Injury Survey, Report on children, January 2005; page 38.

11. Falagas ME, Mourtzoukou EG, Vardakas KZ. Sex differences in the incidence and severity of respiratory tract infections. Respir Med. Sept 2007; 101 (9): 1845-63.

12. Field MJ, Burnet L, Sullivan DR, Stewart P. Clinical biochemistry and metabolism. In: Devidson's Principles \& Practices of Medicine, $22^{\text {nd }}$ edition 2014; Chapter 16, page 427-460.

13. Zilberberg MD, Exuzides A, Spalding J, Foreman A, Jones AG, Colby C \& Shorr AF. Hyponatremia and hospital outcomes among patients with pneumonia: a retrospective cohort study. BMC Pulm Med 2008; 8:16 